\title{
Empathic Metaphor Counseling and Children's Social Responsibilities
}

\author{
Riana Mashar ${ }^{\mathrm{a}}$, Juntika Nurihsan ${ }^{\mathrm{b}}$, Suherman ${ }^{\mathrm{b}}$, M. Solehuddin ${ }^{\mathrm{b}}$ \\ ${ }^{a}$ Universitas Muhammadiyah Magelang, Central Java, Indonesia

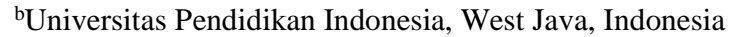 \\ Corresponding e-mail: rianamashar@ummgl.ac.id
}

\begin{abstract}
Based on the preliminary research on early childhood's characters at Elementary School in Magelang, showed that children's responsibilities need to be increased. Social responsibilities has been proven determining one's success in the adulthood and becoming the characteristic of psychologically healthy person. The research aims at investigating the effectiveness of the empathic metaphor counseling to increase children's social responsibilities. Quasi experiment research had been employed as the guideline for this research with untreated control group design by providing pre-test and post-test sample design. The research population were the students at first grade elementary school at SD Muhammadiyah 1 Alternative Magelang. The research sample involved 47 students classified into experiment group (21 students) and control group (26 students). Observation checklists was used in collecting the data. The quantitative data obtained from observation and intelligence tests were analyzed by Anacova (Analysis of Covariance) and anova. The results indicated that (1) the empathic metaphor counseling technique had increased social responsibilities; (2) the empathic metaphor counseling technique more effective to increase boy's social responsibilities than girls.
\end{abstract}

Keywords: Empathic metaphor counseling technique, children's social responsibilities, sex

\section{INTRODUCTION}

Responsibility is the main moral value applied universally and it is the core of many other characters. A responsible individual has ability to realize every single act he/she does and is ready to accept the consequences.

Responsibility's role in personal and social life has been proven determining ones' success in the adulthood (Wenner and Smith, 1989), and becoming the characteristic of psychologically healthy person (Glasser and Zennin in Latipun, 2008; Corey, 2009). Moreover, responsibility formed since elementary school age creates a self-directed learning child (Singapore Ministry of Education, 2014), and makes a child more positively accepted by adults and his/her peers (Tucker, 1994).

The importance of responsibility becomes one of national education success goals as stated in UURI number 20/2003 about National Education System. Mendikbud (in Antaranews, 2010) followed up the national education goals by launching
National Policy of Nation Character Development year 2010-2025. Minister of Education and Culture stated that character education, especially on honesty and responsibility, was going to be implemented in all education levels, but the bigger portion would be given in elementary school. Education world is expected to become the generator to facilitate the development of the nation character.

However, in the reality, it was not easy to achieve the goals national education. The news recently showed various problems in building nation character including responsibility. The problem of low responsibility could be observed from many cases of elementary school students. Bullying case in Bukittinggi elementary school (Sudiaman, 2014), attack by elementary school students in West Java (Tirta, 2013), and in Makasar (PRFM News Channel, 2014) were the phenomenon of character problems that needed to be taken action of.

Problems of daily responsibility can also be seen from the result of the initial research from April 23 to June 9, 2012 in 3 elementary schools in Kota Magelang, consisted of Islamic elementary school, 
state elementary school, and catholic elementary school. The research was done by observing the six dimension of character strength according to Selligman and Peterson (2004) of 92 first grade students from three schools and survey on teachers' perception about children's characters. First grade was chosen because it was the beginning which became the foundation for the success in the next grades. The result of the research gave an overview that the characters of humanity, equity, temperance, and transcendence had not been optimal yet. The students' lowest character was equity which one of the indicators was the students' responsible attitude.

Another survey about character values that needed to be developed on the first grade of elementary students, which involved 77 teachers of first grade of private elementary schools in Magelang Regency, was held in December 2012. The survey resulted: $57 \%$ teachers believed that the most important character values to develop was responsible, $25 \%$ believed it was discipline, $11 \%$ believed it was religious, and 7\% others. From the survey result we can learn that most teachers believed that responsibility was the most important character value to develop since the student started to study in the elementary school. It was based on several reasons, like teachers assumed that responsible students could easily follow the learning process in class and do the task given, was independent, honest, and willing to admit mistakes, did the tasks from the teacher diligently, and could take the consequences of what they did.

The low responsibility in a student needs to be handled seriously as "failure to learn responsibility is related to failure in school, work, and relationship" (Tucker, 1994:1). On the other hand, early responsibility establishment will be the base for establishing other character values and lead the child to success in school, personal and social. Jones (2006) proved that responsibility establishment since elementary school gave positive effect for children and created more conducive class ethos.

Responsibility establishment increases children's obedience to school regulation, escalates selfesteem, and builds better connection with schoolmates and teachers. Responsibility establishment correlates with children's ability to complete the tasks, to participate voluntarily in a form of shown pro-social manner (Thomas, 2011), as well as to develop self-reliant, to be helpful, and ability to collaborate (Ochs and Izquierdo, 2009).

However, concern to character establishment, especially students' responsibility establishment, is still low. Responsibility establishment is affected by many factors. Tucker (1994) stated that children learned responsibility from their parents, school, peers, and community. Besides external factors, responsibility establishment is also affected by internal factors. Piaget and Kohlberg (Santrock, 2002; Beck, 2004) were notable cognitive figures who emphasized the importance of intelligence in a form of child's moral character. While Hoffman, Eisenberg, and Nodding focused more on the roles of affection and emotion in establishing moral characters (Kurtines \& Gerwitz, 1992; Eisenberg, 2000). Hoffman (in Kurtines \& Gerwitz, 1992) stated that empathy became the base of moral acts, especially which were related to motivation in doing the moral acts. Besides intelligence and empathy, establishment of moral character acts is also affected by gender. Gilligan (1982, in Walker, 2006) believed that differences between man and woman affected children's character establishment. Men emphasized more on equity reasoning oriented to cognition, while women emphasized more on concern which oriented to emotion.

Many factors which affect the responsibility establishment cause many obstacles in its development. Solehuddin (2012) observed some main problems happened in character education in Indonesia, whether at home, school, or community. At home which has to be conducive laboratory for children's characters establishment, family has lost lots of its function. Parents' lacks of knowledge, awareness, and skill, as well as social and economic stress have caused parents treat their children inappropriately. It leads to failure for the family to create good environment for character education at home.

The above conditions create opportunity for school to play the role as family partner in carrying on the character learning, especially in elementary school level. Bennet, and co. (1995) stated that elementary school age was important age which helped children to develop habits and values that they will keep in their daily lives. Elementary school was the base for education success in the future, as success in each level depend on the preparation in the previous level.

So far, the effort to develop students' responsibility has been done by teachers in many ways, whether by punishment, warning letter, advice, or habituation, but the student handlings are mostly done individually. Punishments frequently do not work and will affect negatively as children will hate themselves and others (Escarti, Guiterrez, Pascual, and Llpis, 2010), so that it causes the 
children feel lonely and rejected by their social environment (McGinnis and Goldstein, 2003; Katz 2012). The condition needs to be followed-up by providing guidance and counseling service with children development principles.

Counseling for children cannot be carried out as it is for adults. Geldrad and Geldrad (2011:5) stated that:

.......we counsel adults by sitting down with them and inviting them to talk with us, if we were to try to use the same strategy with children....those children would be unlikely to tell us anything importance, they would probably become bored...withdrawn into silence.... as counselors, we are to engage children so that they will talk freely about their painful issues, then we need to use verbal counseling skills in conjunction with other strategies. For example, we might involve the child in play, or in the use of media such as miniature animals, clay or various forms of art. Alternatively, we might involve the child in storytelling, or take them on an imaginary journey. As a consequence the use of verbal counseling skills with the use of media or some other strategy, we are able to create an opportunity for the child to join with us in a therapeutically useful counseling process.

In accordance with Geldrad and Geldrad, Muro and Kottman (1995) stated that counseling for children has different characteristic with the next age stage. Characteristics of children in the age of seven as age of playing, concrete thinking, creativity, imaginative-game-oriented, and age of learning through interaction with teachers and peers in social interaction (Anna Freud in Overby, 2010; Vygotsky in Santrock, 2003; Muro and Kottman, 1995), become the basis for providing metaphor counseling.

Burn (2005) stated that metaphor technique counseling for children was identical with story. It was based on the general principle that children love stories. The use of metaphor story helps children create bridge of personal connection between children and counselor, as well as helps children feel comfortable in the communication. The use of metaphor story can help children to improve identification with characters and events in the story.

Conte (2009) explained that the use of metaphor in counseling can help counselor to insert the message and open the counselee's acceptance of ideas in the story. In term of psychological state, this condition is called narrative transport, a condition that makes counselee's emotion tightly tied with the emotion of the characters in the story. This condition not only makes counselee get the story but also get into the emotional journey as the characters in the story. That was also confirmed by Close (1998:16) who stated that:

Stories address a different level of consciousness than conceptual replies. They elicit a different level of response. Stories trend to be more believable than "objective" statements... A metaphor is not presented as something to be evaluated, but rather as a work of art. It is to be enjoyed and experienced on the basis of its criteria. Metaphors have impressive staying power.

Based on the explanation it can be concluded that the urgency of responsibility as foundation of children's personal and social success needs to be establish early. Nevertheless, the limitation of first grade elementary school teachers in providing guidance and counseling to establish responsibility that fits children's development phase needs to overcome. It triggers the writer to research emphatic metaphor counseling to develop first grade elementary students' social responsibilities.

\subsection{RESEARCH QUESTIONS}

a. How differences social responsibility between control group and experiment group after treated by emphatic metaphor counseling?

b. Hoe effectiveness of metaphor counseling in developing social responsibility in term of students' gender?

\section{RESEARCH METHOD}

The quasi experiment design used in this research was untreathed control group design with dependent pretest and posttest samples (Heppner, Wampold, and Kivlighan, 2008).

Table 1. Quasi-experimental Research Design

\begin{tabular}{ccccc}
\hline & Random & $\mathrm{O}$ & $\mathrm{X}$ & $\mathrm{O}$ \\
\hline Experimen: & $\mathrm{R}$ & $\mathrm{O} 1$ & $\mathrm{X}$ & $\mathrm{O} 2$ \\
\hline Control & $\mathrm{R}$ & $\mathrm{O} 1$ & $\mathrm{X}$ & $\mathrm{O} 2$ \\
\hline
\end{tabular}

Explanation:

O2 : Posttest

$\mathrm{X} \quad$ : Empathic Metaphor Counseling

-X : without Empathic Metaphor Counseling

The population selection of this research was based on characteristics decided by the researcher. The population characteristics were: 
6-7 year-old students, students of the first grade of SD Muhammadiyah 1 Alternatif (SD Mutual) Magelang, not experiencing development obstruction in cognitive aspect, evidenced by IQ test and interview with the teachers result, not experiencing development obstruction in emotional aspect, evidenced by interview with the teachers result, owning responsibility score in category of medium, low, or very low. Simple random sampling was used as sampling technique. Collecting the data use observational checklist with time sampling technique. The data analysis use anacova and anava by SPSS 17.0 for windows programme.

\section{DISCUSSION}

\subsection{There were differences in the increase of responsibility scores in the experimental group which received empathic metaphor counseling treatment compared with control group which did not receive treatment}

Table 2. First Hypotesis Tests of Between-Subjects Effects

\begin{tabular}{cccccccc}
\hline Source & $\begin{array}{c}\text { Type III } \\
\text { Sum of } \\
\text { Square }\end{array}$ & df & $\begin{array}{c}\text { Mean } \\
\text { Square }\end{array}$ & F & Sig. & $\begin{array}{c}\text { Partial } \\
\text { Eta } \\
\text { Squared }\end{array}$ \\
\hline Corrected & $2908.554^{\mathrm{a}}$ & 4 & 727.139 & 7.731 & .000 & .424. \\
Model & 349.797 & 1 & 349.797 & 3.719 & .061 & .081 \\
Intercept & 58.221 & 1 & 58.221 & .619 & .436 & .015 \\
IQ & 1548.482 & 1 & 1548.482 & 16.464 & .000 & .282 \\
Pretest group & 1830.264 & 1 & 1830.264 & 19.460 & .000 & .317 \\
Error & 3950.297 & 42 & 94.055 & & & \\
\hline$\quad$ Total & $\mathbf{2 4 6 2 0 6 . 0 0 0}$ & $\mathbf{4 7}$ & & & & \\
\hline $\begin{array}{c}\text { Corrected } \\
\text { Total }\end{array}$ & $\mathbf{6 8 5 8 . 8 5 1}$ & $\mathbf{4 6}$ & & & & \\
\hline a. R Squared $=.424$ (Adjusted R Squared $=.369)$ & & &
\end{tabular}

Based on the research questions, the objective of the research was to find out the effectiveness of emphatic metaphor counseling in developing children's social responsibilities, which were proven by examining the responsibility score difference after the treatment between experiment group and control group.

The result of the hypothesis showed that the first hypothesis resulted rejected zero hypothesis and accepted alternative hypotheses, so that it can be concluded that there were significant differences between the responsibility scores of experiment group which got treatment and of control group which did not get treatment. The changes of pretest and posttest scores after treatment showed significant differences statistically. Therefore, Empathic Metaphor Counseling was effective to develop children responsibility establishment.

Further analysis test was done to know the effectiveness of empathic metaphor counseling technique in increasing responsibility aspect, both personally and socially. From the result, it could be seen that there were no significant personal responsibility scores differences between control group and experiment group, but significant differences could be seen on social responsibility aspect. It meant that empathic metaphor counseling could effectively increase children's social responsibilities. This condition chiefly dealt with empathic metaphor applied. The higher empathy, the higher social responsibility a child had.

There were three assumptions that can be described about this research. First, the result of the research supported important role of empathy in developing children's responsibility. Second, metaphor counseling was effective to develop responsibility as it fitted children's condition. Third, guidance and counseling application in elementary school was an opportunity to give services with big effect for changes in children to fulfill their development tasks.

The role of empathy in developing children's responsibilities supports the previous researches about the effect of character program intervention to develop students' characters (Larson, 2009; Watson, 2006). Metaphor counseling, which focuses on children's empathy development through metaphor stories, supports the theories of empathy's roles in moral behavior establishment. Empathy in this research could be increased through the exploration 
steps and reframed the metaphor had been given. Some exploration activities emphasized on the question "what would you feel if you became.." or "What would you do if you experience something like...?" Exploring metaphor through questions asked and describing verbal metaphor into visual metaphor would help children connect emotion with cognitive process experienced during the time they were listening to metaphor stories. It correspond the metaphor effect for children according to Geldrad and Geldrad (2011), that stories would help children to identify themselves with the characters, themes, or events in the stories. Children could also reflect themselves in the situation in the stories. The interests on thoughts, emotion, and the manner of the characters in the story would help children project their thoughts, emotion, and themselves. Moreover, metaphor also increases understanding and acquainted new possibilities and perspectives to children (Lyddon, Clay, and Spardk, 2001), as well as has stronger persuasive effect than literal language "metaphorical language has more significantly persuasive effect than literal language" (Sopory and Dillard, 2002:5).

Component of affection is an important part in the mral machine which is going to give power to decide the correct moral reason to do or not to do. Berkowitz (2011:50) explained the important roles of emotion in the early stage of children moral character development. Some of the earliest, most significant hallmarks of the development of character are (1) the beginning of empathy, (2) the development of a concept of persons, and (3) the formation of the attachment bond. Mature empathy entails self-awareness, self-other differentiation, perspective-taking, and the ability to draw inferences about the causes of another's distress.

Affection's big role in establishing character become important hint for parents and teachers in developing children's characters. Teachers are expected to be able to help students to love goodness. Hoffman (1984; in Kurtines \& Gerwitz, 1992) stated that empathy became the basis of moral acts which were related to motivation. What encourage

Empathy's role is frequently associated with one's ability to understand mental condition of someone he/she is facing. Lazarus (1991) defined empathy as one's ability to share feelings with others by putting the psychological condition in accordance with the condition of someone he or she faced. According to Lazarus, empathy was closely related with compassion, whereas the key of compassion was the tendency to help those who were suffering. Empathy was not only feeling sad about others' losses, empathy was defined as imaginative projection toward one's subjective condition, or feelings obtained by observing others' experiences.

Hurlock stated that morality always comprised guilty feeling. Ausubel explained that guilty feeling was one of the most important psychological mechanisms in socialization. Guilty feeling became the guardian within each person that kept the conformity of the person's behavior. If a child did not feel guilty, he or she would not be triggered to learn what was expected by his or her social group or to adjust his or her behavior with the expectation (Hurlock:1978).

Further, Arsenio \& Lemerise (2010) explained the correlation between empathy and emotion awareness, which became the important basis for moral behavior development. The foundation of emotion, which was significant in conscience development, was self-awareness about emotion, such as guilty feeling, pride, shame, and the connection with relevant moral behavior. Many emotional awareness manifested in pride, guilt, and shame were correlated with parents' responses to children's success, failure, obedience, and disobedience. The emotional responses at the beginning were correlated with moral acts of children to anticipating parents' reaction, both which dealt with award and punishment.

Children who can empathize with deficiency or pathetic condition experienced by group of peple, such as poverty, disability, misfortune, and powerlessness will increase guilty feelings within the children when they cannot do something about it as their responsibilities. These guilty feelings appear as the result of their actions that violence the moral values.

Eisenberg (2000) did many researches about empathy's effect toward helping behavior, both on children and adults. The result of the research on adults concluded that adults' abilities to empathize increased the behavior of helping others who suffered misfortune, but rather was intended to lessen unpleasant feeling within themselves. Adults who did not help others who suffered misfortune tend to feel guilty and the egoistical motive to help rather was intended to reduce personal unpleasant feelings. Whereas, empathy research on children showed that children who could empathize to others' misfortunes showed higher helping behavior compared with children showed less empathic feeling. 
The importance of empathy in character building especially children's responsibilities needs to be concerned more carefully by teachers and parents. Children do moral action not only based on what they know but is driven by emotion as the driving force of moral behavior. Therefore, the attempt to develop empathy becomes an important process in children character education. Delors (1996 in Saripah, 2011) stated that:

Moreover, whether education is provided by the family, the community or the school, children should be taught to understand other people's reactions by looking at things from their point of view. Where this spirit of empathy is encouraged in schools, it has a positive effect on young persons' social behavior for the rest of their lives...

Secondly, more specifically, this research also supported the result of the previous research on metaphor counseling effectivity toward children's behavior changes (DeRosier and Mercer, 2007; Prince and Edward, 2010; Geldrad, Yin-Foo, \& Shakespeare-Finch, 2009). Metaphor for children functions to help them understand their experiences. Children process the unfamiliar situation or problem through media, which are familiar in their daily lives during the play of metaphor. Through symbolic metaphor, children can express their emotion in not harmful ways (Geldrad, Yin-Fo, and ShakespeareFinch, 2009).

Children with low responsibility scores are identical with children who often get negative label from their environment. Parents and teachers often take not responsible children as bad, stubborn, disobedient, and other negative labels (result of FGD with teachers and parents). That affects children resistances when they face conditions that cause atmospheres like when they get negative labels. Children who have given negative labels will tend to rarely give positive responses to the advice heard. The use of metaphor in counseling can help children in revealing the issues that make them feel uncomfortable. Sopory and Dillard (2002:5) stated that metaphoric language was significantly more persuasive than literal language. Furthermore, Campbell and Katz (in Kendall, 2010:7) stated that: "Metaphor is a linguistic comparison in which "A in B". A metaphor transfers meaning from a secondary subject usually called the vehicle, to a primary subject, usually called the topic or the base. Through the use of metaphor, meaning is transferred to the topic that might not otherwise be considered". Metaphor here was a behavior changing process through favorable media, which left memories about the messages that would remain long within the children.

According to Geldrad and Geldrad (2011), metaphor encouraged children to communicate naturally. Metaphor stories helped children to identify themselves with the characters, themes, or events in stories. Children's interests in ideas, emotion, and behavior of the characters in the stories helped them project the ideas, emotion, and behavior within themselves. It could be proven based on the result of the counseling process in the stage of metaphor reframing done by the research subject. Subject AR in the seventh counseling section when was asked to' re-frame' a metaphor story about ant and grasshopper, described ant as diligent and grasshopper who liked watching TV, whereas, in the story told there were no grasshopper who liked watching TV. Likewise subject NA who ststed that

"If I were frog, I wouldn't give up to get out of the well.."

Subject FA also showed identification process in the re-framing stage by writing letter to her mother said:

"Mama thanks for giving me love, you're very patient to me, I applogize for hurting you"

Based on the work it can be seen that the subjects identified what were done by the characters in the story. Identification done by the research subjects support many experts' opinions which stated that children were able to identify themselves in the characters of the story (Geldrad and Geldrad, 2011; Marilyn, 2005). Moreover, metaphor is also easy to understand and able to develop children's language competence, to increase children's understanding about world, and to become connecting bridge between insight and feeling. Children often find difficulty in expressing what they feel verbally, but through metaphor they can precisely express the feeling. That conditions help counselees improve attitude as persuasive effect of metaphor. "Metaphoric language was significanly more persuasive than literal language" (Sopory dan Dillard, 2002:5). During the counseling process, metaphor appears in form of story which is connected with therapeutic potential (Burn,2005). Metaphor affects on the communication with counselee about experiences, process, or effects which can help children solve problem and give new 
meaning as the coping for the problems faced (Marilyn and co., 2005).

Third, metaphor effectiveness in developing children responsibility is a way of giving guidance and counseling which is relatively simple and easy to apply by the teachers at school. Children responsibility establishment since early childhood will encourage children to become selfdirected learners (Ministry of Education Singapore, 2014), makes children accepted more positively by adults and peers (Tucker, 1994), and is proven determining the success in the adulthood (Werner and Smith, 1989). This condition will encourage children to achieve their developing tasks as the foundation for accomplishing their developing tasks in the next period.

Elementary school teachers as guidance and counseling for children service provider need to pay attention to the following principles: (1) counseling for seven year-old children is usually a very active process, the use of playing and playing media are still needed accompanied by the use of verbal technique as in this age children's thinking ability and logic have increased. Guidance activities in the classroom through group discussion will succeed well in group of seven year-old children. (2) This age is marked with children's ability to do amazing self-analysis. They can list their weaknesses and strengths without much help from the counselors. (3) Group of seven year-old children enables counselors to focus more on feeling as they start to understand the feelings they experience and are better in giving labels and discussing what they feel. (4) Fantasy is an important part in seven year-old children's lives. Children like 'wild' stories very much, and some children think their fantasies are real. (5) Children can involve in the counseling process which takes longer time. Age of seven implication in counseling process will be able to help counselor in applying correct counseling principals for children in that age (Mur and Kottman). By concerning those principals, it is hoped that teachers can keep giving more precise and quality guidance and counseling service.

Metaphor counseling in form of stories which are effective in developing children responsibilities can also be correlated with the advantages of the modules of metaphor counseling which involve three main learning principals for children. Siregar (2010) stated that story books could build children's characters if contained three learning principles, i.e. containing model that can be duplicated by children, containing habituation designed in assignment for children, and giving reinforcement for the readers.
Metaphor counseling has applied those three principles. Each metaphor story contains characters that can be good model for children. Besides that, metaphor counseling modules are equipped with assignments which have to be completed by children after listening to the metaphor story. Furthermore, in metaphor counseling modules, the counselor has provided reinforcement for children who can join the activities well in the form of responsibility quotes stickers.

Referred to the result of the observation on the subjects' responsibilities scores after treatment, it was found that the experiment group showed increasing responsibility scores. Nevertheless, if it was observed based on responsibility aspect, it could be known that the scores in term of personal responsibility did not show significant differences with control group which scores were as high as the scores before the treatment. It was different with the scores in term of social responsibility. The analysis result proved that there were significant differences in social responsibility scores between control group and experiment group after treatment. It meant that metaphor counseling was more effective to develop social responsibility rather than personal responsibility.

The result was also supported by the result of focus group discussion (FGD) with the teachers and the principal. From the FGD result, it could be concluded that the habit in SD Mutual emphasized on competition and instilment of values in term of personal responsibilities. The school emphasized so much on students' obedience to follow the rules, to do homework, to wear uniform tidily, to do sholat on time, not to come late, to be winner, and to obey teachers. Many of those values emphasizing were less balanced with instilment on social responsibility. Principal and teachers admitted their weakness in stimulating collaboration, concern, helping each other, respect, and many ethics in making interpersonal relationship, for the reason of the limited time and activities to develop those values.

Beside the school's habit factor, the higher personal responsibility of first grade students could also be caused by the factor of each individual's development. Linda and Eyre (1994) stated that at the beginning children learned responsibilities from the parents, which were shown in obedience to parents. Then responsible to the society for who and what they were (morality), developed into responsibility for themselves (discipline), and at last developed into responsibility for others (service). In other words, in early childhood, responsibility was 
applied in obedience to something and many tasks, along with their growth, children would feel responsible for what they have done. the more mature the children, they will take responsibility on their choices, characters and potentials. at the end of childhood, children will develop responsibility to others. Therefore, at the age of 6-7, it is still normal if the responsibility development process is still oriented to personal responsibility. Age and right stimulus from the surroundings will sharpen their social responsibilities.

\subsection{The effectiveness of Empathic Metaphor Counseling difference between girls and boy}

F score results showed 0.039 with $(\mathrm{p}=0.961>\mathrm{p}=$ 0.05). It's mean that there's no significant differences between girls and boys. But, from pretest and posttest score, showed that pretest score between girls and boys had F score 5.114 with significant level at $\mathrm{p}=0.29<\mathrm{p}=0.05$. And $\mathrm{F}$ score of posttest 0.025 with significant level at $\mathrm{p}=0.875>$ $\mathrm{p}=0.05$. It's mean that the empathic metaphor counseling can increase the boy's social responsibilities scores.

The result of the hypothesis test proved that there was no effectiveness difference in metaphor counseling technique to increase responsibility in terms of students' gender. It was proven by the absence of significant differences of the male and female subjects' average scores. By the observation on the difference of pretest and posttest scores, it could be seen that at the beginning of measurement, there were differences between male and female subjects' responsibility scores, but after getting treatment, male subjects' responsibility scores increased $s$ that there were no responsibility scores differences between male and female subjects.

Based on pretest score, the result of research agreed the theory of Gilligan (in Walker, 2006). If it was associated with empathy, women in any ages showed higher empathy level than men (Barnett, and c., 1980; Eisenberg and Mussen, 1978; McDevitt, Lenon, and Kopriva, 1991). The research result which showed differences between men and women moral development were supported by researches by Gilligan (in Shumaker, 2007). However, the research result based on posttest scores, on the other hand, supported other researches which showed no moral differences between men and women. Walker (2006), in his study, reviewed 80 researches about moral differences of men and women. Walker concluded that $86 \%$ of the researches showed no differences in moral development of men and women. The next study by Jaffe and Hyde (2000) on meta-analysis research concluded that from 113 researches on moral orientation, $73 \%$ did not show significant gender differences in moral reasoning ethic.

The absence of differences of empathic metaphor counseling effectiveness on the responsibility posttest scores based on gender showed that counseling which focused on children empathy improvement affected the responsibility improvement, especially on boys. It gave opportunity to emotional stimulus for boys to develop empathy as the moral act booster. This result was supported by research which proved that the effect of parenting and training could reduce empathy gap between men and women (Eisenberg and Mussen (1978); Haynes and Avery (1979); Clarke (1984).

\section{CONCLUSIONS}

Empathic metaphor counseling's effective to increase social responsibilities on elementary children. This condition chiefly dealt with empathic metaphor applied. The higher empathy, the higher social responsibility a child had. There were three assumptions that can be described about this research. First, the result of the research supported important role of empathy in developing children's responsibility. Second, metaphor counseling was effective to develop responsibility as it fitted children's condition. Third, guidance and counseling application in elementary school was an opportunity to give services with big effect for changes in children to fulfill their development tasks. This technique more effective for boys than girls. Boys who receive empathic metaphor counseling can improve their social responsibilities.

\section{REFERENCES}

Arsenio, W.F. \& Lemerisse, E.A. (2010). Emotion, aggression, and morality in children; bridging development and psychopathology. Washington DC: American Psychological Association

Barker, P. (1996). Psychotherapeutic metaphor: a guide to theory and practice. New York: Brunner/Mazel, Inc. (2013). Using metaphor in psychotherapy. New York: Brunner/Mazel, Inc. 
Battino, R. (2002). Metaphoria: Metaphor and guided metaphor for psychotherapy and healing. Williston USA: Crown House Publishing Ltd.

Beaty. C. (2008). Child Behavior. New Jersey: John Wiley \& Sons, Inc.

Beck, Laura E. (1994). Child development, 3th edition. Boston: Allyn and Bacon

Bennet, W. 1995. The Children Book of Virtues. New York: Simon and Schuster

Berkowitz, M.W. (2011). The science of character education. DP5HPDAMO0300 rev 1 pp.: 4363. Diakses 07 Januari 2013 dari http://hooverpressdamon.com

Berkowitz, M.W. \& Bier, M.C. (2007). What Works in Character Education. Journal of Research in Character Education, 5 (1), pp. 29-48. Information Age Publishing, Inc. ISSN: 15431223

Birch, J. \& Carmichael, K.D. (2009). Using drawings in play therapy: A Jungian approach. The Alabama Counseling Association Journal, Vol. 34, Number 2, pp. 2-7.

Boeree, C. G. (2006). Personality theories of Carl Rogers. Diakses pada tanggal 19 Juli 2012 dari http://rogersfocus.com

Brown, Nina W. (1994). Group counseling for elementary and middle school children. London: Greenwood Publishing Group, Inc.

Burns, G.W. (2005). 101 Healing stories for kids and teens, using metaphor in therapy. Ner Jersey: John Wiley \& Sons, Inc.

CEP (2008). Performance values, why they matter and what schools can do to foster their development. Journal of Research in Character Education, 6(1), pp. 73-81. Information Age Publishing, Inc. ISSN: 1543-1223

Chapman, R. (2009). The use of metaphor in counselling: A discourse analysis. Thesis. Vancouver: The University of British Columbia

Chartrand, M.S. (2013). Gender differences in child development. Diakses tanggal 07 Januari 2015 dari http://www.drmaxchartrand.org.

Chesley, Gayle et all. (2008). Verbal and nonverbal metaphor with children in counseling. Journal of Counseling and Development, No. 86 Fall 399-411.

Close, Henry T. (1998). Metaphor in psychotherapy, clinical application of stories and allegories. California: Impact Publishers.
Conte, C. (2009). Advanced technique for counseling and psychotherapy. New York: Springer Publishing Company.

Corey, Gerald. (2009). Teori dan praktik konseling dan psikoterapi. Bandung: Refika Aditama

Creagh, S. (2004). Pendidikan seks SMA di Yogyakarta. Yogyakarta: Kerjasama Australian Consortium for in Country Indonesian Studies dan FISIP Universitas Muhammadiyah Malang. http://www.acicis.murdoch.edu.au/hi/field_topi cs/screagh.pdf. Diakses tanggal 14 Oktober 2011

Creswell, J.W. \& Clark, V.L.P. (2007).

Designing and conducting mixed methods research. London: Sage Publications

Davis, T.E. (1997). Telling life stories and creating life books: A counseling technique for fostering resilience in children. Dissertation. Virginia: Virginia Polytechnic Institute and State University.

DeRosier, M.E \& Mercer, S.H. (2007). Improving student social behavior the effectiveness of a storytelling-based character education program. Journal of Research in Character Education, Vol. 5 (2). Pp. 131-148. Information Age Publishing, Inc.

Drake, C. (2011). Values education: The heart of character development. Proceeding National Seminar on Character as Essence of Children's Development. Yogyakarta: Universitas Negeri Yogyakarta

Escar, Guiterrez, Pascual, and Llopis. (2010). Implementation of the personal and social responsibility model to improve self-efficacy during physical education classes for primary school children. International Journal of Psychology and Psychological Therapy. Vol. 10 No. 3, pp387-402.www.ijpsy.com

Eisenberg, N. (2000). Empathy and sympathy, Handbook of Emotion, second edition by Lewis \& Havilland- Jones. New York: The Guilford Press.

Foot, H., Woolfson, L., Terras, M., \& Norfolk, C. (2004). Handling hard to manage behaviors in preschool: Provision, A System Approach. Journal of Early Childhood Research. Vol. 2(2), 115-138.

Frasier, R.C. (2013). Helping children develop responsibility. http://parentchild.com. Diakses tanggal 14 Oktober 2013. 
Geldard, K \& Geldard, D. (2011). Counselling children, A practical introduction, Third Edition. Illinois: SAGE Publications Ltd. Geldard, Yin-Foo, \& Shakespeare-Finch, (2009). How to using a fruit tree like you? Using metaphors to explore and develop emotional competence in children. Australian Journal of Guidance and Counselling. 19(1). Pp. 1-13. Diakses pada tanggal 10 November 2014. http://eprints.qut.edu.au/

Gibson, R.L. \& Mitchell, M. H. (1995). Introduction to counseling and guidance. Columbus, Ohio: Prentice- Hall, Inc.

Geldard, Yin-Foo, \& Shakespeare-Finch, (2009). How to using a fruit tree like you? Using metaphors to explore and develop emotional competence in children. Australian Journal of Guidance and Counselling. 19(1). Pp. 1-13. Diakses pada tanggal 10 November 2014. http://eprints.qut.edu.au/

Glenn, S. (1989). Raising self-reliant children: In A self-indolent world. Rocklin California: Prima Publishing

Grasmick, N.S., Brooks, D., O’Malley, Martin. Carter. J.L., Chafin, A.E. (2007). Character education by design, a blueprint for successful district and school initiatives. Maryland State Department of Education.

Greenberg, P (1991). Character development: Encouraging self-esteem and self-discipline in infants, toddlers, and 2 year olds. Washington DC: National Association for Education of Young Children.

Greenberg, L.S. (2002). Emotion-Focused Therapy, coaching clients to work through their feelings. Washington: American Psychological Association.

Hasan, A.B.P. (2006). Psikologi . (2010). Rekonseptualisasi dan perkembangan islami, menyingkap rentang kehidupan manusia dari prakelahiran hingga pascakematian. Jakarta: PT Rajawali Grafindo Persada.

Hastings, P. D., Utendale, W. T., \& Sullivan, C. (2007). The socialization of prosocial development In J. E. Grusec \& P. D. Hastings (Eds.), Handbook of socialization theory and research (pp.638-664). New York: Guilford.Hidayat, T. 2004. Agar anak tidak pendek akal. Republika, Minggu, 11 Juli 2004.

Heppner, P.P, Wampold, B.E, Kivlighan, D.M. 2008. Research design in counseling. Belmont: Thomson Higher Education.
Hockney, H.L. \& Cormier, S. (2009). The Professional counselor, A process guide to helping, sixth edition. Ohio: Pearson Education, Inc.

Hurlock, E. (1978). Child development, sixth edition. New York: McGraw-Hill, Inc.

Kartadinata, S. (2011). Menguak Tabir Bimbingan dan Konseling sebagai Upaya Pedagogis. Bandung: UPI Press

Kartadinata, S. (2010). Review on Philosophy, Theory, and Practice of Developmental Guidance and Counseling, A Good Way to Grow, Guidance and Counseling for All. www.bkperkembanganrevewonphilo sophy.com. Diakses tanggal 7 Desember 2010.

Profesionalisasi Bimbingan dan Konseling Perspektif Keterpaduan Hidup Belajar-Bekerja. Materi Power Point (tidak diterbitkan). Bandung: UPI

Katz, Laurie. (2012). Inclusive in Classroom. Materi Kuliah (tidak diterbitkan). Colombus: Ohio State University

Kendall, W.A. (2010). Examining the persuasive effect of metaphor use in psychotherapy: An experimental test of contributing factors. A Dissertation. New York: University of Albany.

Kok, J.K., Lim, C.M., \& Low, S.K. (2011). Attending to metaphor in counselling. International Conference on Social Science and Humanity, IPEDR Vol. 5 (2011). Singapore: IACSIT Press.

Kopp, R.R. (1995). Metaphor therapy: Using clientgenerated metaphors inpsychotherapy. New York: Brunner/Mazel.

Kostelnik, M.J., Soderman, A.K., \& Whiren, A.P. (1999). Developmentally Appropriate Curriculum, Best Practices in Early Childhood Education. New Jersey: Prentice Hall

Kurtines, W.M. \& Gerwitz, J.L. (1992). Moralitas, perilaku moral, dan perkembangan moral, terjemahan oleh Soelaeman. Jakarta: UI Press

Lackoff, G., \& Johnson, M. (2003). Metaphors we live by. Chicago: The University of Chicago Press.

LaFreniere, P.J. (2000). Emotional development, a biosocial perspective. Belmont: Wadsworth/Thomson Learning.

Larson, K. (2009). Understanding the importance of character education. University of WisconsinStout.

Latipun. (2008). Psikologi konseling. Malang: UMM Press. 
Lazarus, R.S. (1991). Emotion and adaptation. New York: Oxford University Press.

Lickona, T. 1991. Educating for Character: How Our School Can Teach Respect and Responsibility. New York: The New York Times Company.2005. Traditional View of Character and Character Education. New York: State University of New York.

Lickona, T \& Davidson, M. 2005. Smart and Good High Schools: A Report to the Nation. Greensboro, NC: Character Development Group.

Linda \& Eyre, R. (1994). Teaching your Children Responsibility. New York: A Fireside Book Inc.

Lyddon, W.J., Clay, A.L., \& Sparks, C.L. (2001). Metaphor and change in counselling. Journal of Counselling and Development, Vol. 79, pg. 269-274.

Marilyn, et all. (2005). Creative Metaphors in Life Experiences Seen in Play Therapy. Diakses tanggal 5 Mei 2013, dari: www.psikologizone.com /.

Martin, J., Cummings, A.L., dan Hallberg, E.T. (1992). Therapists' intentional use of metaphor: Memorability, clinical impact, and possible epistemic/motivational functions. Journal of Consulting and Clinical Psychology, 60, 143-145.

McGinnis, E \& Goldstein. (2003). Skill streaming in early childhood, Revised Edition, New Strategies and Perspectives for Teaching Prosocial Skills. Illinois: Research Press.

Megawangi, R. (2010). Pengembangan program karakter di sekolah: Pengalaman sekolah karakter. Diakses pada tanggal 07 Januari 2014, dari: http://www.pustaka.ut.ac.id/dev25/ pdfprosiding2/fkip201002.pdf

Merry, T. (1997). Interview Counseling and Creativity: An Interview with Natalie Rogers. British Journal of Guidance \& Counselling, Vol. 25, No. 2. London: Department of Psychology, University of East London.

Mirrell, K.W. (2003). Behavioral, Social, and Emotional Assessment of Children and Adolescents, second edition. New Jersey: Lawrence Erlbaum Associates, Publishers.

Merry, T. (1997). Interview Counseling and Creativity: An Interview with Natalie Rogers. British Journal of Guidance \& Counselling, Vol. 25, No. 2. London: Department of Psychology, University of East London

Miles, M.B. \& Huberman, A.M. (1992). Analisis data kualitatif. Jakarta: UI Press.
Ministry of Education Singapore. (2014). Primary school education, preparing your child for tomorrow. www.moe.gov.sg

Muro, J.J \& Kottman, T. (1995). Guidance and Counseling in the Elementary and Middle Schools, a Practical Approach. Iowa: WCB Brown \& Benchmar.

Nye, R.D. (2000). Three Psychologies Perspectives from Freud, Skinner, and Rogers, 6th Edition. United State: Wadsworth Thomson Learning.

Ochs, E \& Izquierdo, E. (2009). Responsibility in Childhood: Three Developmental Trajectories. ETHOS: Journal of the Society for Psychological Anthropology, Vol. 37, Issue 4, pp. 391-413, ISSN 0091-2131

Overby, Renee. (2010). what do them (Anna Freud, Jean Piaget, and Erik Erikson) Know about My Children, Anyway?

Www.reneeoverby.com. Diakses pada tanggal 29 April 2010.

O’Sullivan, Sheryl. (2012). Book to Live By: Using Children's Literature for Character Education: Social Development, Research Impact on Academic Achievement and Literacy Development. USA: Zaner-Blosder, Inc.

Papalia, D.E., Olds, S.W., dan Feldman, R.D. 2002. A Child's World, Infancy through Adolescence. Ninth Edition. Boston: McGraw Hill

Parke, W. (2013). Teaching Children Responsibility. http://fatherhood.about.com/old/su ccedingasafather/a/teach responsibility.htm. Diakses tanggal 14 Oktober 2013

Pearson, Q., dan Nicholson, J. (2000). Comprehensive character education in the elementary school: Strategies for administrators, teachers, and counselors. Journal of Humanistic Counseling, Education \& Development, 38, 243. Diakses tanggal 10 November 2013, dari: http://ezproxy.lib.uwstout.edu

Seligman \& Peterson (2004). Character Strengths and Virtues: A Handbook and Classification. Washington DC: American Psychological Association

Solehuddin, M. (2012). Strengthening character education in early childhood, prosiding seminar internasional penguatan pendidikan karakter pada jenjang pendidikan dasar di era global. Bandung: UPI- Logos Publisher

Sopory, P., dan Dillard, J.P. (2002). The persuasive effects of metaphor: a meta-analysis. Human Communication Research, 28, 382-419. 
Thomas, R. (2011). Autonomy, responsibility, and families: keynote address presented at 12 th international conference on theory and education, Barcelona, Spain. Diakses dari http://www.internationalconference_theoryand.

Tucker, B. (2012). Building Responsibility, How to Teach My Children to be More Responsible. Arizona: The University of Arizona

Watson, Marilyn, (2006). Long-Term Effect of Moral/Character Education in Elementary School, In Pursuit of Mechanism. Journal of Research in Character Education, 4 No 1\&2, pp. 1-18. Information Age Publishing, Inc. ISSN 1543-1223

Werner dan Smith. (1989). Vulnerable but invincible: a longitudinal study of resilient children and youth. New York: Adam, Bannister and Cox 